\title{
Gravity and Magnetic Studies of the Eastern Mojave Desert, California and Nevada
}

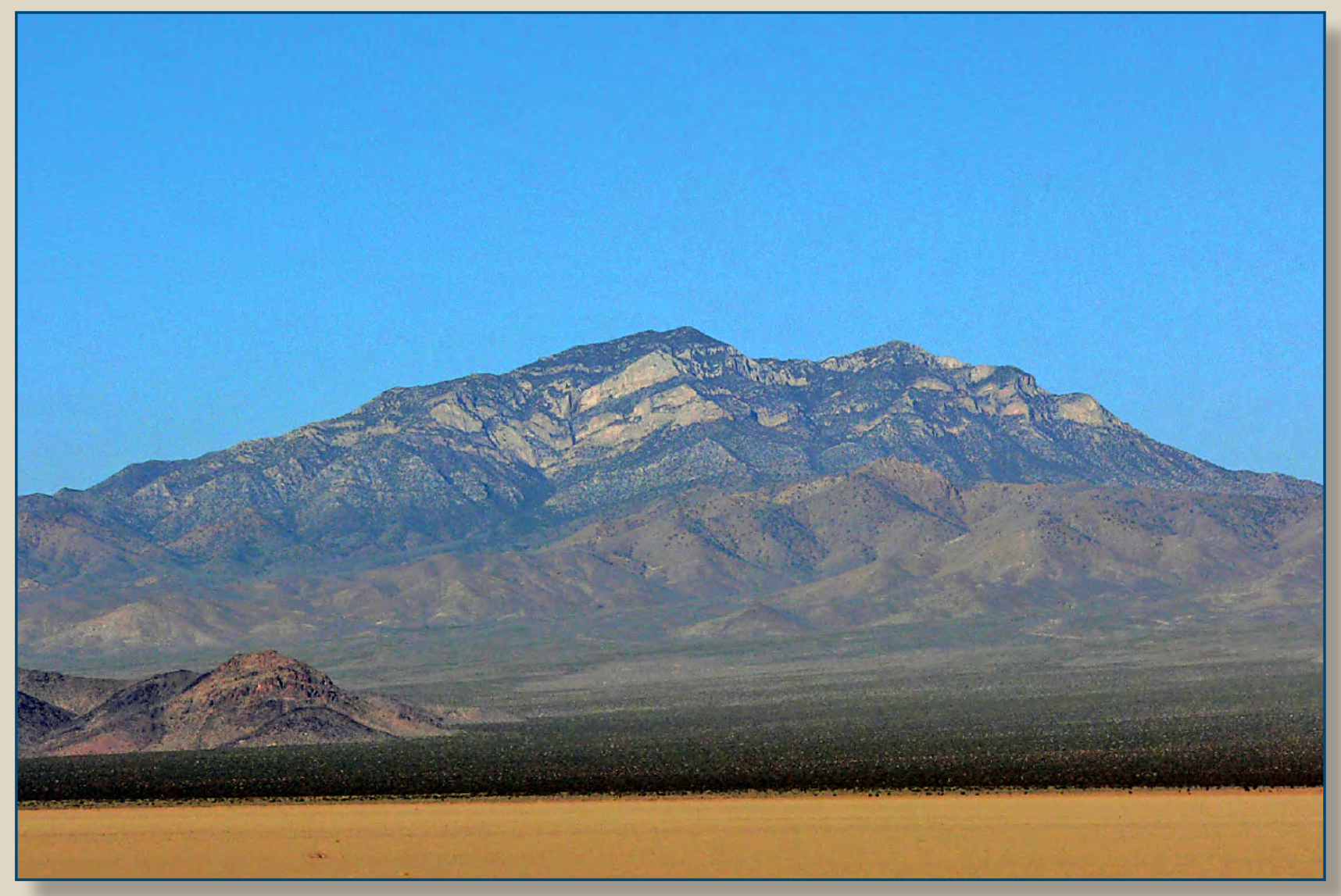

Open-File Report 2016-1070

Version 1.1, August 2018

U.S. Department of the Interior

U.S. Geological Survey 
Cover: Photograph of Clark Mountain Range, California. View northwestward. Photograph by K.M. Denton, U.S. Geological Survey. 


\section{Gravity and Magnetic Studies of the Eastern Mojave Desert, California and Nevada}

By Kevin M. Denton and David A. Ponce

Open-File Report 2016-1070

Version 1.1, August 2018

U.S. Department of the Interior

U.S. Geological Survey 


\section{U.S. Department of the Interior SALLY JEWELL, Secretary}

\section{U.S. Geological Survey \\ Suzette M. Kimball, Director}

\section{U.S. Geological Survey, Reston, Virginia}

First release: 2016

Revised: August 2018 (ver. 1.1)

For an overview of USGS information products, including maps, imagery, and publications, visit http://www.usgs.gov/pubprod/.

Any use of trade, firm, or product names is for descriptive purposes only and does not imply endorsement by the U.S. Government.

Although this information product, for the most part, is in the public domain, it also may contain copyrighted materials as noted in the text. Permission to reproduce copyrighted items must be secured from the copyright owner.

Suggested citation:

Denton, K.M., and Ponce, D.A., 2018, Gravity and magnetic studies of the eastern Mojave Desert, California and Nevada (ver 1.1, August 2018): U.S. Geological Survey Open-File Report 2016-1070, 20 p., http://dx.doi.org/10.3133/ofr20161070. 


\section{Contents}

Introduction

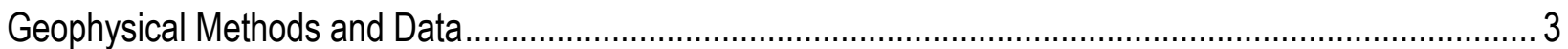

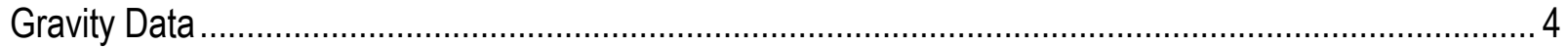

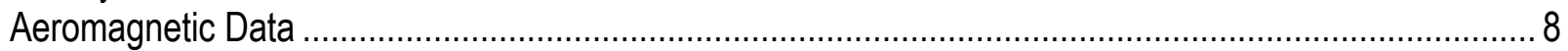

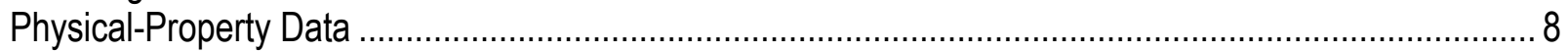

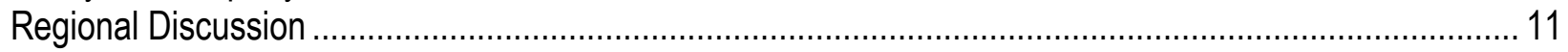

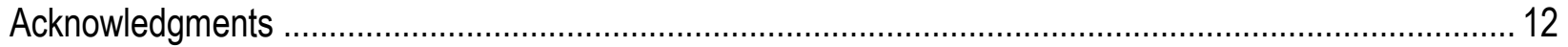

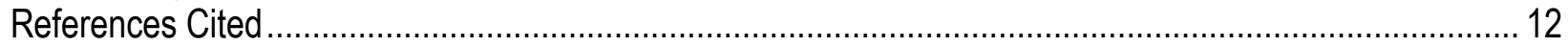

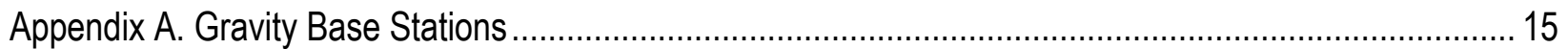

\section{Figures}

Figure 1. Index and simplified geologic map of the eastern Mojave Desert, California and Nevada............ 2

Figure 2. Simplified geologic map showing locations of gravity stations and physical-property collection sites, eastern Mojave Desert, California and Nevada................................................................ 5

Figure 3. Isostatic gravity map of the eastern Mojave Desert study area, California and Nevada. .............. 7

Figure 4. Aeromagnetic map of the eastern Mojave Desert study area, California and Nevada .................. 9

\section{Tables}

Table 1. Gravity data and description of format and accuracy codes ...................................................... 6

Table 2. Physical property data and descritpion of format ............................................................. 8

Table 3. Explanation of rock modifier and rock types listed in table 2 .................................................. 8

Table 4. Selected physical-property data by rock type ................................................................... 10

\section{Conversion Factors and Datum}

SI to Inch/Pound

\begin{tabular}{lll}
\hline Multiply & By & To obtain \\
\hline \multicolumn{3}{c}{ Length } \\
\hline meter $(\mathrm{m})$ & 3.28084 & foot $(\mathrm{ft})$ \\
kilometer $(\mathrm{km})$ & 0.6213 & mile $(\mathrm{mi})$ \\
\hline \multicolumn{3}{c}{} \\
\hline milligal $(\mathrm{mGal})$ & Acceleration & \\
\hline
\end{tabular}

\section{Datum}

Horizontal coordinate information is referenced to the North American Datum of 1927 (NAD27). 
This page intentionally left blank. 


\title{
Gravity and Magnetic Studies of the Eastern Mojave Desert, California and Nevada
}

\author{
By Kevin M. Denton and David A. Ponce
}

\section{Introduction}

From May 2011 to August 2014, the U.S. Geological Survey (USGS) collected gravity data at more than 2,400 stations and physical property measurements on more than 640 rock samples from outcrops in the eastern Mojave Desert, California and Nevada (fig. 1). Gravity, magnetic, and physical-property data are used to study and locate regional crustal structures as an aid to understanding the geologic framework related to mineral resources of the eastern Mojave Desert.

The eastern Mojave Desert is host to a world-class rare earth element carbonatite deposit located at Mountain Pass, California. Carbonatites are typically defined as magmatic rocks with high modal abundances of primary carbonate minerals $>50$ weight percent and elevated abundances of rare earth elements (REEs) (Nelson and others, 1988; Woolley and Kempe, 1989). The "Sulphide Queen" carbonatite ore deposit is a composite, tabular body made up of sills and dikes of REE-bearing sovites and beforsites that occurs just south of the Clark Mountain Range along a north-northwest trending fault-bounded block that extends along the northeast edge of the Mescal Range and northwestern extent of Ivanpah Mountains (fig. 1). This early to middle Proterozoic block is composed of a $1.7 \mathrm{Ga}$ metamorphic complex of gneiss and schist that underwent widespread metamorphism and associated plutonism during the Ivanpah orogeny (Miller and others, 2007). Subsequently, these rocks were intruded by a series of granitoids, which included the $1.4 \mathrm{Ga}$ (DeWitt and others, 1987) ultrapotassic alkaline suite of intrusions that are spatially and temporally associated with hundreds of dikes, outcrops, and a carbonatite ore body. The relative age sequence of this intrusive suite of alkaline rocks from oldest to youngest includes shonkinite, mesosyenite, syenite, quartz syenite, potassic granite, carbonatite, and late shonkinite dikes (Olson and others, 1954; Wooden and Miller, 1990; Haxel, 2005; Miller and others, 2007).

A thick sequence of younger sedimentary rocks unconformably blanket the entire Proterozoic terrane in the eastern Mojave Desert. During the Mesozoic, widespread volcanism and plutonism ensued. The middle and late Mesozoic were characterized by regional crustal shortening and uplift along the Sevier fold and thrust belt. Although much of the early Cenozoic was quiescent, Miocene volcanism was widespread along the margins of the region and accompanied by significant extension. Locally, the Mountain Pass area escaped much of this extension (Olson and others, 1954; Burchfiel and Davis, 1971; Wooden and Miller, 1990; Miller and others, 2007; Theodore, 2007; Tosdal, 2007; Jessey and others, 2013). 


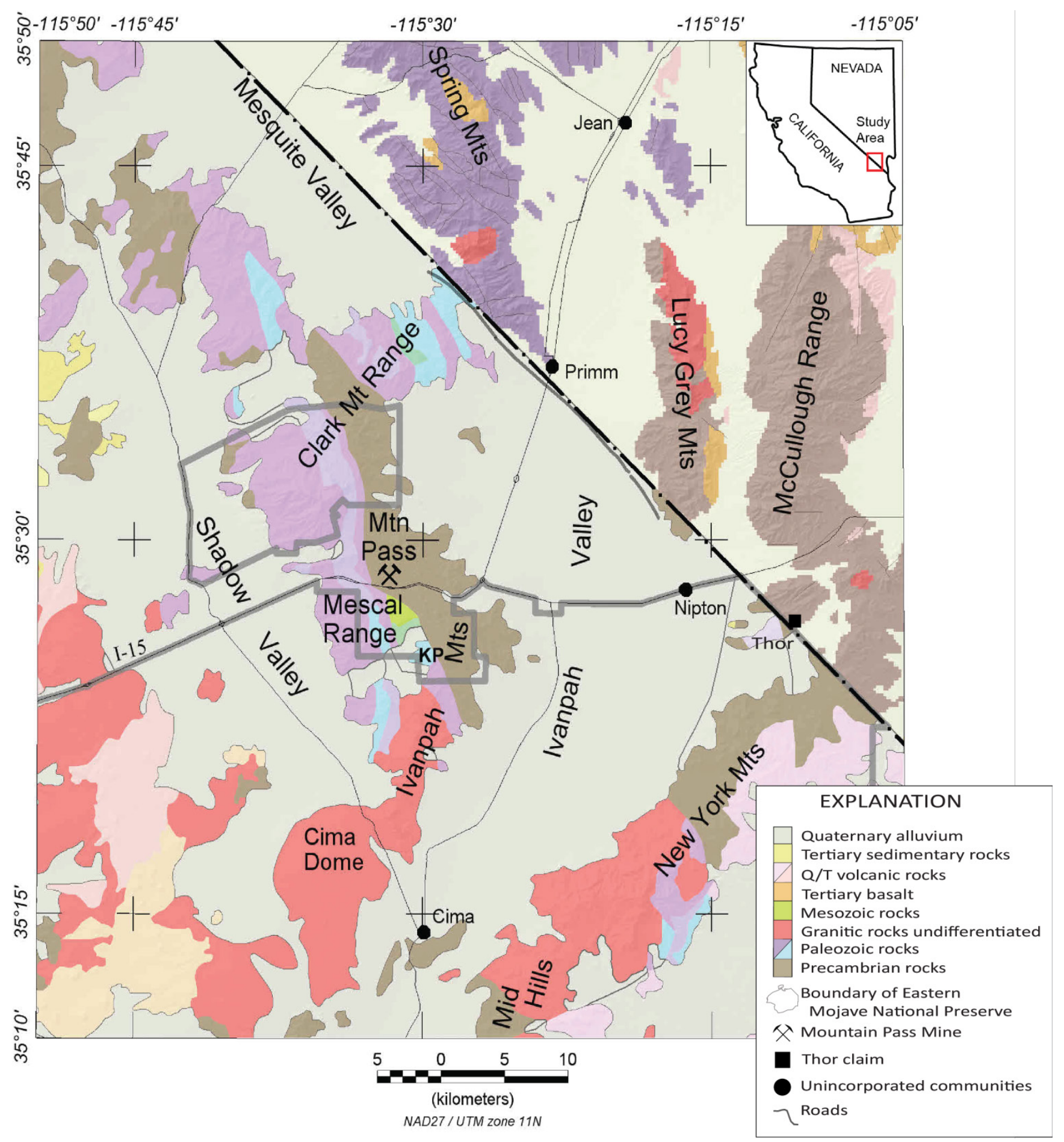

Figure 1. Index and simplified geologic map of the eastern Mojave Desert, California and Nevada (from Jennings and others, 1977; Stewart and Carlson, 1978). Bold gray line, Mojave National Preserve; KP, Kokoweef Peak. 
In addition to the metamorphic and alkaline suite of intrusive rocks, other geologic units present in the eastern Mojave Desert include:

- Late Proterozoic to Ordovician limestone, siltstone, shale, quartzite, and dolomite (for example, Zabriskie Quartzite, Carrera Formation, Nopah Formation, Bonanza King Formation, Pogonip Group, Sultan Limestone, Bird Spring Formation, and Kaibab Formation);

- Triassic limestone, shale, and sandstone (Moenkoepi Formation);

- Mesozoic volcanic and sedimentary rocks that include volcanic flows, tuff, shale, sandstone, conglomerate, and limestone; a Jurassic hornblende diorite and syenogranite to monzogranite (for example, Delfonte volcanic rocks, Aztec Sandstone, and Ivanpah granite); and

- Cretaceous granitoid rocks including the Teutonia batholith; and

- Tertiary and Quaternary unconsolidated deposits that include gravel, alluvial fan deposits, and alluvium (see Olson and others, 1954; Hewett, 1956; Burchfiel and Davis, 1971, 1981; Beckerman and others, 1982; Jessey and others, 2001; Miller and others, 2007).

\section{Geophysical Methods and Data}

Gravity and magnetic data were collected and processed in such a way that they reflect lateral changes in subsurface density and magnetic properties, respectively. Because rock types vary in density (by about a factor of two) and have a wide range in magnetic properties (several orders of magnitude), gravity and magnetic data can be used to infer their occurrence and resulting subsurface extent. Gravity data are typically more difficult to process than magnetic data because they require the removal of non-geologically related effects, such as the tidal attraction of the Moon and Sun, instrument drift, changes in gravity with elevation, changes in gravity with latitude, Earth's curvature, and the surrounding topographic terrain. Magnetic data are simply corrected for diurnal variations in the Earth's magnetic field, magnetic effects of the airplane (if applicable), and for a regional geomagnetic model of the Earth.

Gravity and magnetic anomalies can be used to infer the subsurface structure of known or unknown geologic features, provided a physical-property contrast occurs across the geologic boundaries. Gravity anomalies can, for example, reveal variations in lithology and delineate features such as calderas, deep sedimentary basins, and faults, all of which play an important role in defining the geologic framework of a region. Similarly, magnetic anomalies reveal changes in lithology and are well suited for delineating faults. Generally, short-wavelength, high-amplitude magnetic anomalies are caused by moderately to strongly magnetic volcanic rocks, whereas broad circular long-wavelength magnetic anomalies reflect magnetic granitoid intrusions or other mafic basement rocks. 


\section{Gravity Data}

Gravity data were collected between May 2011 and September 2014 at 2,321 stations concentrated in areas of poor control, as well as along traverses of interest (fig. 2). Gravity stations were distributed from west to east across parts of Shadow Valley, Clark Mountain Range, Mescal Range, Ivanpah Mountains, Cima Dome, Cima, Spring Mountains, Jean, Ivanpah Valley, Lucy Grey Mountains, Nipton, and New York Mountains. All gravity data were tied to primary base stations (PRIMM and PVR-A, appendix A) in Primm, Nevada and a secondary field base station (MTN PASS, appendix A) established near the intersection of Bailey Road, just south of Interstate 15 at Mountain Pass, California. These stations were ultimately tied to a high-precision gravity base station (PB1021, appendix A) near Baker, California described by Robert and Jachens (1986) as part of their southern California high-precision gravity base station network and to a World Relative Gravity Reference Network of North America gravity base station at Nipton, California (Jablonski, 1974; appendix A).

Gravity data were processed using standard methods (Blakely, 1995) and included the following corrections: (1) an earth-tide correction, which corrects for tidal effects of the Moon and Sun; (2) an instrument-drift correction, which compensates for drift in the instrument's spring; (3) a latitude correction, which accounts for variation in the Earth's gravity with latitude; (4) free-air correction, which accounts for the variation in gravity due to elevation relative to sea level; (5) a Bouguer correction, which corrects for the attraction of material between the station and sea level; (6) a curvature correction, which corrects the Bouguer correction for the effect of the Earth's curvature; (7) a terrain correction, which removes the effect of topography to a radial distance of $167 \mathrm{~km}$ from the station; and (8) an isostatic correction, which removes long-wavelength variations in the gravity field related to the compensation of topographic loads.

LaCoste and Romberg and Scintrex CG-5 gravity meters were used in this study. Gravity meter readings were converted to gravity units for LaCoste and Romberg gravity meters by using factory calibration constants, as well as a secondary calibration factors determined by multiple gravity readings over the Mount Hamilton calibration loop east of San Jose, California (Barnes and others, 1969). For the Scintrex CG-5 gravity meters, the factory meter calibration constant was also checked and a secondary calibration factor was determined over the Mount Hamilton calibration loop. Observed gravity values were based on a time-dependent linear drift between successive base readings and referenced to the International Gravity Standardization Net 1971 (IGSN 71) gravity datum (Morelli, 1974, p. 18). Free-air gravity anomalies were calculated using the Geodetic Reference System 1967 formula for theoretical gravity on the ellipsoid (International Union of Geodesy and Geophysics, 1971, p. 60) and Swick's (1942, p. 65) formula for the free-air correction. Bouguer, curvature, and terrain corrections were added to the free-air anomaly to determine the complete Bouguer anomaly at a standard reduction density of $2,670 \mathrm{~kg} / \mathrm{m}^{3}$. Finally, a regional isostatic gravity field was removed from the Bouguer field by assuming an AiryHeiskanen model for isostatic compensation of topographic loads (Jachens and Roberts, 1981), with an assumed nominal sea-level crustal thickness of $25 \mathrm{~km}$, a crustal density of $2,670 \mathrm{~kg} / \mathrm{m}^{3}$, and a density contrast across the base of the crust of $400 \mathrm{~kg} / \mathrm{m}^{3}$. Gravity values are expressed in milligal (mGal), a unit of acceleration or gravitational force per mass equal to $10^{-5} \mathrm{~m} / \mathrm{s}^{2}$.

Station locations and elevations were obtained using a Trimble GeoXH differential Global Positioning System instrument. The GeoXH receiver uses the Wide Area Augmentation System which, in combination with a base station and post processing with a Continually Operated Reference Station, results in submeter vertical accuracy. 


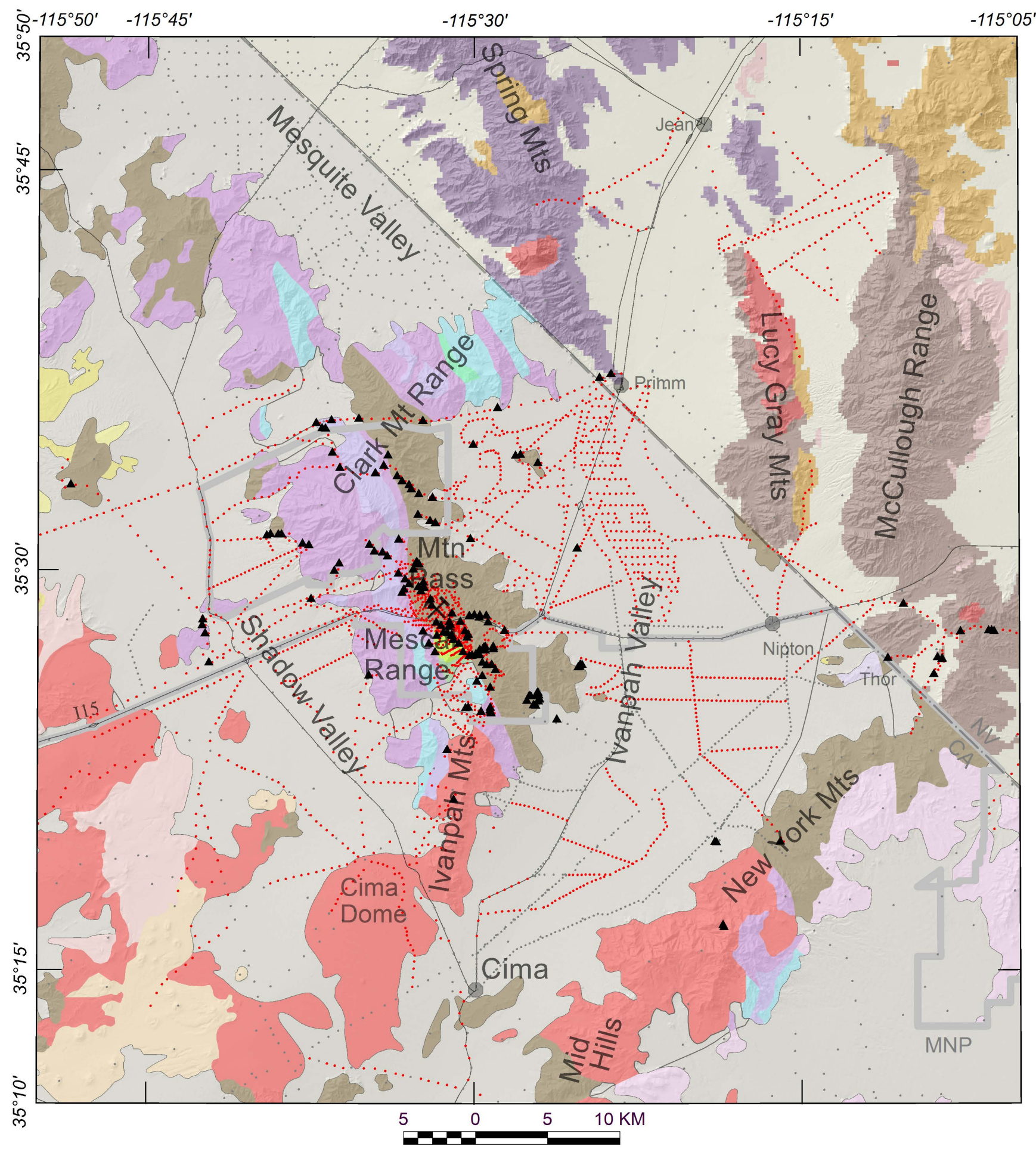

Figure 2. Simplified geologic map showing data-collection sites, eastern Mojave Desert, California and Nevada. Red circle, gravity stations collected during this study; gray circle, pre-existing gravity station (Ponce, 1997; Langenheim and others, 2009); black triangle, physical-property site location; bold gray line, Mojave National Preserve boundary. 
Terrain corrections, which account for the variation in topography near a gravity station, were calculated using a combination of manual and digital methods. Terrain corrections consist of a three-part process: an innermost or field-terrain correction, an innerzone-terrain correction, and an outerzone-terrain correction. The innermost-terrain correction, which was estimated in the field, extends from the station to a radial distance of $68 \mathrm{~m}$ and is equivalent to the outer radius of Hayford and Bowie's (1912) zone B. The innerzone-terrain correction, which was estimated from a digital elevation model (DEM) with 10- or 30-m resolution derived from USGS 7.5-minute topographic or lidar maps, extends from $68 \mathrm{~m}$ to a radial distance of $2 \mathrm{~km}$ (D. Plouff, U.S. Geological Survey, unpub. data, 2006). The outerzone-terrain correction, which was calculated by using a DEM derived from USGS 1:250,000-scale topographic maps and an automated procedure based on geographic coordinates (Plouff, 1966, 1977; Godson and Plouff, 1988), extends from 2 $\mathrm{km}$ to a radial distance of $167 \mathrm{~km}$. Digital terrain corrections were calculated by computing the gravity effect of each grid cell in the DEM, using the distance and difference in elevation of each grid cell from the gravity station.

Data from new gravity stations were combined with data from pre-existing gravity stations (Ponce, 1997; Langenheim and others, 2009) from the surrounding area in California and Nevada (fig. 2), and their principal facts are listed and their format described in a Microsoft ${ }^{\circ}$ Excel workbook (table 1). All gravity data were gridded using a minimum curvature algorithm at an interval of $500 \mathrm{~m}$ and displayed as a color-contoured isostatic gravity map (fig. 3). Observed gravity values are accurate to about $0.05 \mathrm{mGal}$, and calculated gravity anomalies to about 0.5 mGal.

Table 1. Gravity data and description of format and accuracy codes. [Table 1 is a Microsoft ${ }^{\circ}$ Excel file and can be downloaded at https://pubs.er.usgs.gov/publication/ofr20161070] 


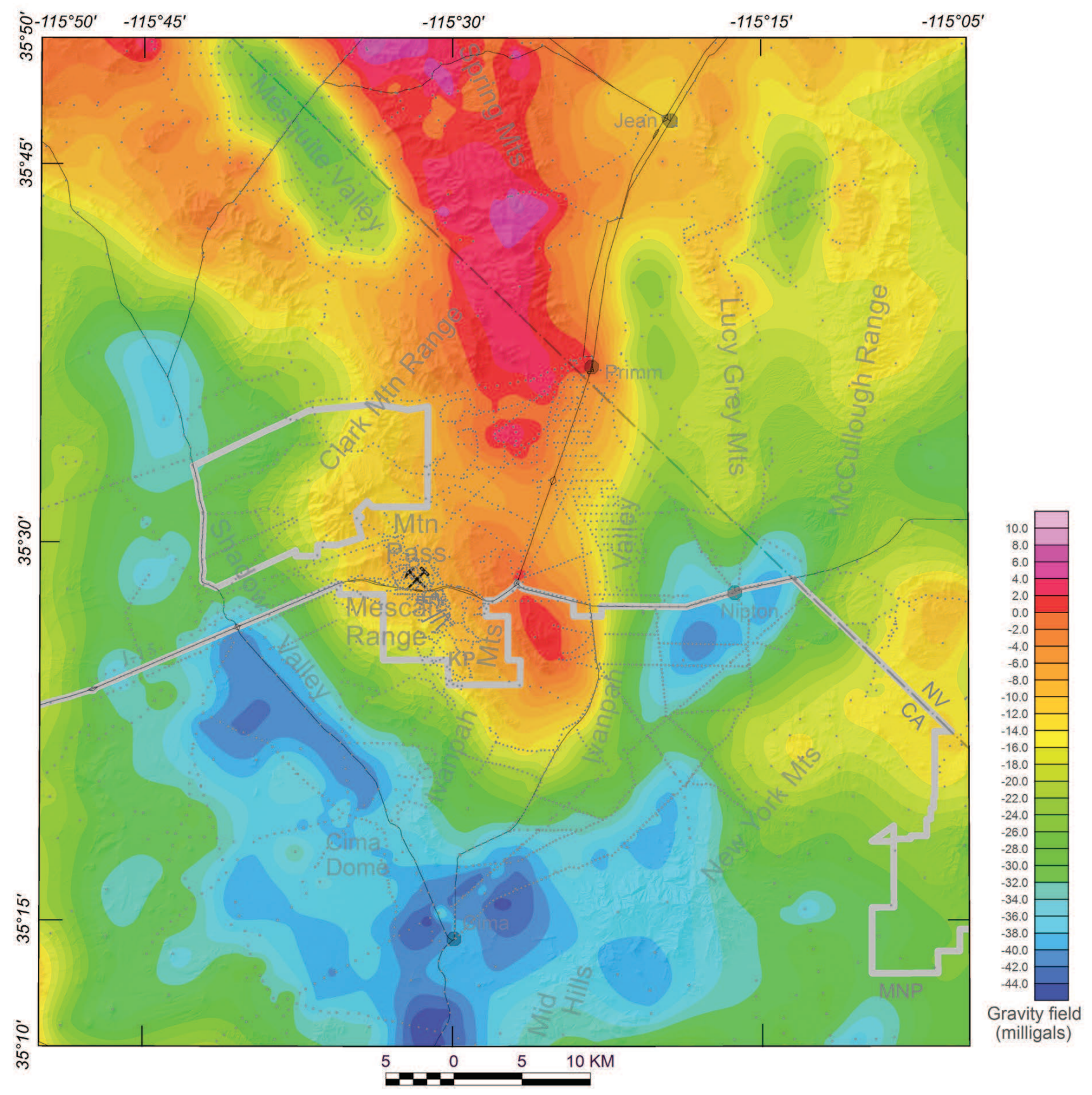

Figure 3. Isostatic gravity map of the eastern Mojave Desert study area, California and Nevada. Grey circle, gravity station; bold gray line, Mojave National Preserve. 


\section{Aeromagnetic Data}

An aeromagnetic map of the study area (fig. 4) was derived from multiple surveys of parts of California (Roberts and Jachens, 1999) and Nevada (Kucks and others, 2006). Aeromagnetic data were mosaicked together by Roberts and Jachens (1999) and Kucks and others (2006) and corrected for diurnal variations of the Earth's magnetic field. Individual surveys were either mathematically upward or downward continued to a constant elevation of $305 \mathrm{~m}$ above the ground, adjusted to a common datum, and finally merged to produce a uniform map with a grid spacing of $500 \mathrm{~m}$. Although composed of multiple surveys acquired with different specifications, this compilation allows for seamless interpretation of magnetic anomalies across survey boundaries.

Aeromagnetic surveys in the study area have a range in flight-line spacing from 0.4 to 3.2 $\mathrm{km}$, and a range in flight-line altitude from 0.15 above ground to $2.7 \mathrm{~km}$ barometric elevation. However, most of the study area has a poor spatial resolution with flight-line spacing of 1.6 to 3.2 $\mathrm{km}$ and a flight-line altitude of $2.7 \mathrm{~km}$ barometric elevation. Widely spaced surveys or those flown at higher flight-line altitudes may lack resolution needed to resolve shallow magnetic sources in some parts of the aeromagnetic map. However, these issues are not significant for the generalized and regional-scale magnetic interpretations presented here.

\section{Physical-Property Data}

Physical-property data were collected from 643 locations throughout the study area from outcrops, a geothermal well in the Clark Mountain Range (C.W. Williams and S.P. Galanis, U.S. Geological Survey, written commun., 2012), and from selected core samples from drillholes at the Thor claim in the New York Mountains (fig. 1). Physical-property data are listed and their format described in a Microsoft ${ }^{\mathfrak{Q}}$ Excel workbook (tables 2 and 3), and a summary of selected density and magnetic susceptibility measurements by rock type is listed in table 4 . Digital data include station identifier, geographic coordinates (NAD27), rock type, density, and magnetic susceptibility. Densities were determined by the buoyancy method, and weights were measured using an electronic balance with an accuracy of $\pm 0.01 \mathrm{~g}$. Magnetic susceptibility was measured using a Kappameter model KT-5 and a GF Instruments model SM20 with an accuracy of $0.01 \times 10^{-3} \mathrm{SI}$ unit. Grain, saturated-bulk, and dry-bulk densities were calculated for each sample by weighing the sample in air $\left(W_{a}\right)$, saturated and submerged in water $\left(W_{w}\right)$, and saturated and weighed in air (Was), using the following formulas, where all weights are measured in grams:

$$
\begin{gathered}
\text { Grain density }=1,000 \mathrm{~kg} / \mathrm{m}^{3} * W a /(W a-W w), \\
\text { Saturated-bulk density }=1,000 \mathrm{~kg} / \mathrm{m}^{3} * W a s /(W a s-W w) \text {, and } \\
\text { Dry-bulk density }=1,000 \mathrm{~kg} / \mathrm{m}^{3} * W_{a} /\left(W_{a s}-W_{w}\right) .
\end{gathered}
$$

Table 2. Physical property data and description of format.

[Table 2 is a Microsoft ${ }^{\circ}$ Excel file and can be downloaded at https://pubs.er.usgs.gov/publication/ofr20161070]

Table 3. Explanation of rock modifier and rock types listed in table 2.

[Table 3 is a Microsoft ${ }^{\circ}$ Excel file and can be downloaded at https://pubs.er.usgs.gov/publication/ofr20161070] 


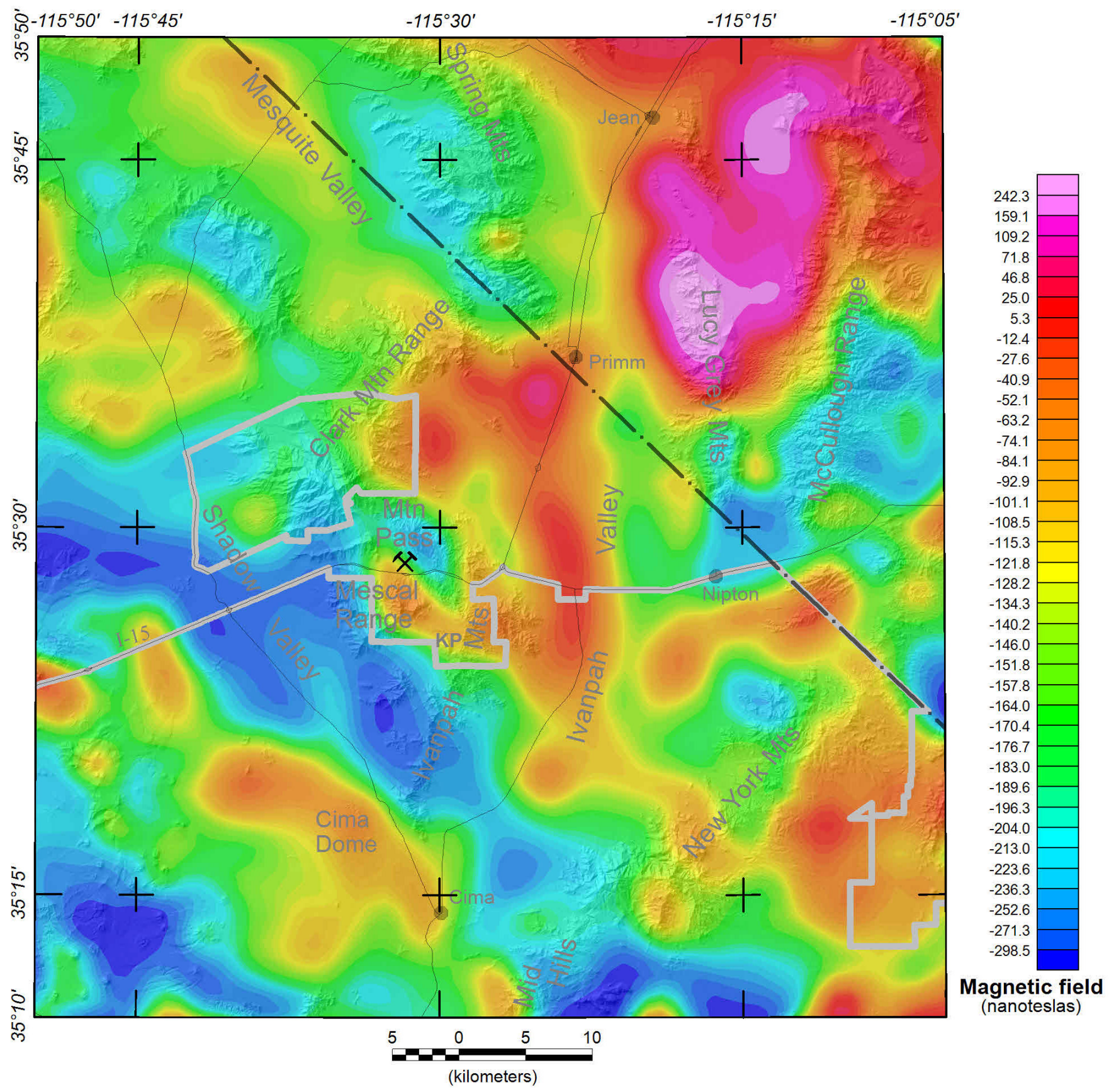

Figure 4. Aeromagnetic map of the eastern Mojave Desert study area, California and Nevada. Bold gray line, Mojave National Preserve; KP, Kokoweef Peak. 
Density and magnetic properties of rocks are important constraints for the interpretation of gravity and magnetic anomalies and are critical parameters for modeling the subsurface extent of geologic units. Physical-property measurements of representative rock types in the area (table 4) show that 31 samples of carbonatite ore have an average saturated bulk density (the representative or in situ density) of $2,993 \mathrm{~kg} / \mathrm{m}^{3}$ and are essentially non-magnetic with an average susceptibility of $0.1810^{-3}$ SI units; 17 samples of syenite have an average saturated bulk density of $2,670 \mathrm{~kg} / \mathrm{m}^{3}$ and a very weak average magnetic susceptibility of $3.47 \times 10^{-3}$ SI units; 12 samples of shonkinite have an average saturated bulk density of $2,834 \mathrm{~kg} / \mathrm{m}^{3}$ and are essentially nonmagnetic with an average magnetic susceptibility of $0.11 \times 10^{-3} \mathrm{SI}$ units; and 28 samples of Proterozoic gneiss have an average saturated bulk density of $2,733 \mathrm{~kg} / \mathrm{m}^{3}$ and an average magnetic susceptibility of $1.23 \times$ $10^{-3} \mathrm{SI}$ units. In summary, carbonatite rocks are much denser than the surrounding rocks and most rocks sampled thus far in the study area are only weakly magnetic.

Table 4. Selected physical-property data by rock type.

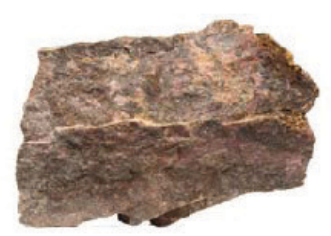

a) Carbonatite

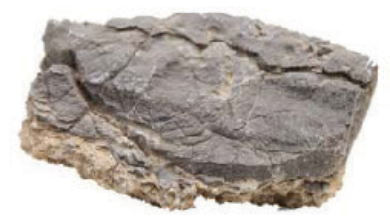

b) Dolomite

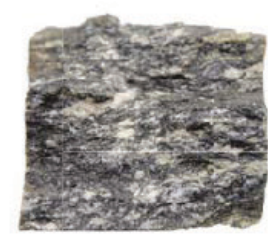

c) Gneiss

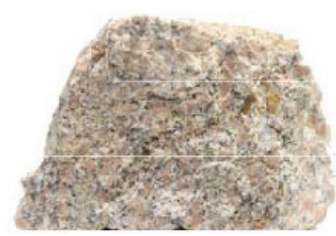

d) Granite

\begin{tabular}{|c|c|c|c|c|c|c|c|c|c|c|}
\hline $\begin{array}{l}\text { Rock } \\
\text { type }\end{array}$ & $\begin{array}{c}\text { Number } \\
\text { of } \\
\text { samples }\end{array}$ & $\begin{array}{l}\text { Grain } \\
\text { density } \\
\mathrm{kg} / \mathrm{m}^{3}\end{array}$ & Range & $\begin{array}{c}\text { Saturated- } \\
\text { bulk density } \\
\mathrm{kg} / \mathrm{m}^{3}\end{array}$ & Range & $\begin{array}{c}\text { Dry-bulk } \\
\text { density } \\
\mathrm{kg} / \mathrm{m}^{3}\end{array}$ & Range & $\begin{array}{c}\text { Magnetic } \\
\text { susceptibility } \\
\times 10^{-3} \mathrm{SI}\end{array}$ & & ange \\
\hline a) Carbonatite & 31 & 3068 & $2537-3628$ & 2993 & $2440-3591$ & 2956 & $2376-3577$ & 0.18 & 0.03 & -0.61 \\
\hline b) Dolomite & 31 & 2765 & $2659-2852$ & 2734 & $2573-2847$ & 2715 & $2521-2843$ & 0.00 & 0.00 & -0.04 \\
\hline c) Gneiss & 28 & 2762 & $2599-3093$ & 2733 & $2574-3086$ & 2716 & $2547-3082$ & 1.23 & 0.01 & $\begin{array}{l}-7.48 \\
\end{array}$ \\
\hline d) Granite & 20 & 2644 & $2591-2720$ & 2617 & $2541-2704$ & 2600 & $2502-2695$ & 0.82 & 0.01 & -3.44 \\
\hline e) Monzogranite & 11 & 2640 & $2590-2696$ & 2601 & $2553-2665$ & 2578 & $2526-2647$ & 0.38 & 0.06 & -2.05 \\
\hline f) Quartzite & 3 & 2724 & $2608-2805$ & 2683 & $2575-2798$ & 2683 & $2575-2798$ & 0.03 & 0.01 & -0.05 \\
\hline g) Shonkinite & 12 & 2879 & $2768-3030$ & 2834 & $2647 \quad 3000$ & 2810 & $2578-2985$ & 0.11 & 0.07 & -4.45 \\
\hline h) Syenite & 17 & 2710 & $2593-2825$ & 2670 & $2555-2788$ & 2647 & $2531-2767$ & 3.47 & 0.19 & -11.46 \\
\hline
\end{tabular}

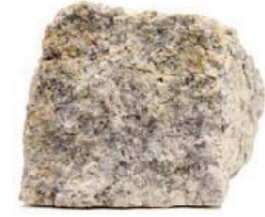

e) Monzogranite

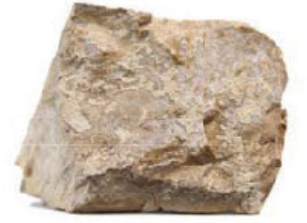

f) Quartzite

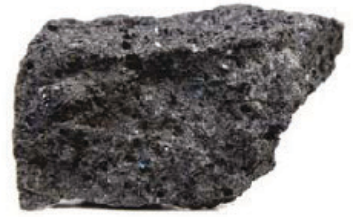

g) Shonkinite

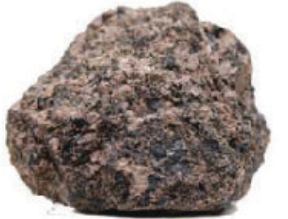

h) Syenite 


\section{Regional Discussion}

Generally, carbonatite ore bodies have distinctive gravity, magnetic, and radiometric signatures because they are relatively dense, associated with magnetite, and are typically enriched in thorium. The carbonatite body at Mountain Pass, Calif. is primarily composed of carbonate minerals (for example, calcite), however it contains nearly $25 \%$ barite $\left(4.50 \mathrm{~g} / \mathrm{cm}^{3}\right)$ and $12 \%$ bastnasite $\left(4.90 \mathrm{~g} / \mathrm{cm}^{3}\right)$ which accounts for its relatively high specific gravity (Castor, 2008). While some carbonatites do contain primary magnetite (for example, Nesbitt and Kelly, 1977; Shive and others, 1990; Drenth, 2014), the carbonatite body at Mountain Pass contains little to no magnetite (the most common magnetic anomaly producing mineral), thus the carbonatite deposit itself is characterized as a central magnetic low. In addition, other rocks associated with the carbonatite body such as: the REE enriched ultrapotassic alkaline intrusive suite, surrounding Proterozoic gneiss and schist host rocks, and the Paleozoic rocks exposed at the surface are also only weakly magnetic.

Previous gravity and magnetic studies in the eastern Mojave terrane are limited in areal extent or are general in nature (Carlisle and others, 1980; Swanson and others, 1980; Hendricks, 2007; Langenheim and others, 2009). From west to east, Shadow Valley is characterized by a 20 mGal gravity low (fig. 3) that is associated with relatively low density basin fill material. Although data coverage is sparse, gravity data indicate that the depth to basement rocks is probably about 1.5 $\mathrm{km}$, based on a semi-infinite sheet assuming a $20 \mathrm{mGal}$ gravity anomaly and an average density contrast between basin fill and basement rocks of $400 \mathrm{~kg} / \mathrm{m}^{3}\left(0.4 \mathrm{~g} / \mathrm{cm}^{3}\right)$. An iterative depth to basement method incorporating geology, gravity, and drill-hole data applied to the entire Mojave National Preserve (bold gray line, fig. 1) indicates that Shadow Valley reaches a maximum depth of about $1.5 \mathrm{~km}$ (Langenheim and others, 2009). Magnetic anomalies are quite subdued and of low amplitude in Shadow Valley (fig. 4), suggesting that there are no near surface magnetic rocks in this area except in the northeastern part of the valley along the western margin of the Clark Mountain Range and within the Mojave National Preserve. Here, a moderate amplitude circular magnetic anomaly indicates the presence of a moderately magnetic granitoid intrusion below the surface or, less likely, the presence of volcanic rocks.

The Clark Mountain Range, Mescal Range, and the northeastern Ivanpah Mountains are characterized by gravity highs that are associated with relatively dense Cambrian dolomite and Proterozoic gneiss (fig. 3). In those locations, magnetic anomalies are more complex, with a magnetic high on the eastern part of Clark Mountain Range and a magnetic ridge extending southeastward from the Mountain Pass carbonatite deposit (fig. 4). The magnetic high along the eastern margin of the Clark Mountain Range is probably related to moderately magnetic Proterozoic basement rocks (Hendricks, 2007). Although Hendricks (2007) suggested that the magnetic ridge extending southeast from the carbonatite body may be related to the ultrapotassic rocks and carbonatite, physical-property data show that these rocks are essentially nonmagnetic and are probably not the source of the magnetic high. Moderately magnetic intrusions or mafic crystalline basement rocks in the region could be the source of the magnetic high. Alternatively, the magnetic low over the carbonatite body and alkali intrusive suite in this area (fig. 4) could be related, in part, to a subsequent alteration event that destroyed magnetic minerals. The southwestern parts of the Ivanpah Mountains are characterized by a gravity low that reflects relatively lower density granitoid rocks. Magnetic anomalies along the western parts of the Clark Mountain Range, Mescal Range, and Ivanpah Mountains are quite subdued, indicating that these sedimentary rocks are essentially nonmagnetic and relatively thick (fig. 4). 
Ivanpah Valley is characterized by prominent gravity and magnetic anomalies (figs. 3 and 4). These anomalies indicate that dense and moderately magnetic rocks occur along the central and western margins of Ivanpah Valley at relatively shallow depths. In the northwestern parts of Ivanpah Valley, Cambrian to Devonian Goodsprings Dolomite and preCambrian garnetiferous gneiss are exposed in small outcrops (Hewett, 1956). Based on seismic refraction, magnetic, and gravity data, Carlisle and others (1980) suggest that Ivanpah Valley is an asymmetric graben, deeper along the southeastern margin and that the depth to basement or thickness of "sediments" is about $2.4 \mathrm{~km}$. This compares well to drill-hole data with depths to basement of $1.9 \mathrm{~km}$ in the southeastern part and depths of 0.7 and $1.1 \mathrm{~km}$ in the central part of the valley (Carlisle and others, 1980; Hodgson, 1980). Basin depths inferred from the inversion of gravity data by Langenheim and others (2009) suggest that most of Ivanpah Valley is quite shallow, less than about $500 \mathrm{~m}$ near the Clark Mountain Range, but may reach depths greater than about $3 \mathrm{~km}$ near Nipton, California. Swanson and others (1980) suggested that the Clark Mountain fault at about $6 \mathrm{~km}$ southeast of Kokoweef Peak (KP, fig. 1) may extend more southerly into Ivanpah Valley rather than more easterly as mapped by Hewett (1956) based on seismic refraction and magnetic data. However, the extension of the Clark Mountain fault south of Interstate 15 is uncertain (for example, Jessey and others, 2001; Jessey, 2013).

The diverse physical properties of the rocks that underlie the study area (fig. 1) are well suited to geophysical investigations. The contrasts in density and magnetic properties between preCenozoic crystalline basement and the overlying Tertiary volcanic rocks and unconsolidated alluvium, for example, produce a distinctive pattern of gravity and magnetic anomalies that can be used to infer subsurface geologic structure. Recently acquired gravity and physical-property data described herein will aid in understanding the geologic framework of the eastern Mojave Desert.

\section{Acknowledgments}

We thank Jay Bridgeman, Bruce Chuchel, Jacob DeAngelo, Pete Galanis, Gordon Haxel, Clayton Jernigan, Carson MacPherson-Krutsky, Dave Miller, Doug Morton, Monica Mustain, Brent Ritzinger, Colin Williams, and Steve Wilson of the U.S. Geological Survey; and Mike Berger and Graham Lederer for their office and field support. We thank John Landreth, Dan Cordier, and Brittany Ruiter of Molycorp, Inc., Debra Hughson and David Nichols of the Mojave National Preserve, and Doug Davis and Amanda Schieb with the Ivanpah Solar Power Facility for facilitating our efforts. We thank David Jessey of California State Polytechnic University, Pomona and Suzanne Baltzer for access to core samples from the Thor claim in the New York Mountains. We also thank Bruce Chuchel and Darcy McPhee of the U.S. Geological Survey for reviewing the report and Carolyn Donlin, Jeffery L. Suwak, and Linda S. Rogers for their editorial suggestions.

\section{References Cited}

Barnes, D.F., Oliver, H.W., and Robbins, S.L., 1969, Standardization of gravimeter calibrations in the Geological Survey: Eos, American Geophysical Union Transactions, v. 50, no. 10, p. 626-627.

Beckerman, G.M., Robinson, J.P., and Anderson, J.L., 1982, The Teutonia batholith-A large intrusive complex of Jurassic and Cretaceous age in the eastern Mojave Desert, California, in Frost, E.G., and Martin, D.M., eds., Mesozoic-Cenozoic tectonic evolution of the Colorado River region, California, Arizona, and Nevada: San Diego, California, Cordilleran Publishers, p. 205-220.

Blakely, R.J., 1995, Potential theory in gravity and applications: New York, Cambridge University Press, $441 \mathrm{p}$. 
Burchfiel, B.C., and Davis, G.A., 1971, Clark Mountain thrust complex in the Cordillera of southeastern California-Geologic summary and field trip guide, in Elders, W.A., ed., Geological excursions in southern California: Riverside, University of California, Campus Museum Contributions Number 1, p. 128 .

Burchfiel, B.C., and Davis, G.A., 1981, Mojave Desert and environs, in Ernst, W.G., ed., The geotectonic development of California (Rubey Vol. I): Englewood Cliffs, N.J., Prentice-Hall, p. 217-252.

Carlisle, C.L., Luyendyk, B.P., and McPherron, R.L., 1980, Geophysical survey in the Ivanpah Valley and vicinity, eastern Mojave Desert, California, in Fife, D.L., and Brown, A.R., eds., Geology and mineral wealth in the California Desert: South Coast Geological Society, Dibblee Volume, no. 8, p. 485-494.

Castor, S.B., 2008, Rare earth deposits of North America: Resource Geology, v. 58, p. 337-347.

DeWitt, E., Kwak, L.M., and Zartman, R.E., 1987, U-Th-Pb and 40Ar/39Ar dating of the Mountain Pass carbonatite and alkalic igneous rocks, southeastern California: Geological Society of America Abstracts with Programs, v. 19, no. 7, p. 642.

Drenth, B.J., 2014, Geophysical expression of a buried niobium and rare element deposit: the Elk Creek carbonatite, Nebraska, USA: Interpretation, v. 2, p. SJ169-SJ179, doi:10.1190/INT-2014-0002.1.

Godson, R.H., and Plouff, D., 1988, BOUGUER version 1.0, a microcomputer gravity-terrain-correction program: U.S. Geological Survey Open-File Report 88-644-A, 22 p.

Haxel, G.B., 2005, Ultrapotassic mafic dikes and rare earth element- and barium-rich carbonatite at Mountain Pass, Mojave Desert, southern California-Summary and field trip locations: U.S. Geological Survey Open-File Report 2005-1219, 55 p.

Hayford, J.F., and Bowie, W., 1912, The effect of topography and isostatic compensation upon the intensity of gravity: U.S. Coast and Geodetic Survey Special Publication 10, 132 p.

Hendricks, J.D., Geophysics, 2007, in Theodore, T.G., ed., Geology and mineral resources of the east Mojave National Scenic Area, San Bernardino County, California: U.S. Geological Survey Bulletin 2160, p. 81-87.

Hewett, D.F., 1956, Geology and mineral resources of the Ivanpah quadrangle, California and Nevada: U.S. Geological Survey Professional Paper 275, 172 p.

Hodgson, S.F., ed., 1980, Oil and gas prospect wells drilled in California through 1980: California Division of Oil and Gas Publication TRO 1, 258 p.

International Union of Geodesy and Geophysics, 1971, Geodetic reference system 1967: International Association of Geodesy Special Publication 3, 116 p.

Jablonski, H.M., 1974, World relative gravity reference network North America, Parts 1 and 2, with a supplementary section on IGSN 71 gravity datum values (rev. ed.): U.S. Defense Mapping Agency Aerospace Center Reference Publication 25, 1,261 p.

Jachens, R.C., and Roberts, C.W., 1981, Documentation of a FORTRAN program, 'isocomp', for computing isostatic residual gravity: U.S. Geological Survey Open-File Report 81-574, 26 p.

Jennings, C.W., Strand, R.G., and Rogers, T.H., 1977, Geologic map of California: California Division of Mines and Geology, scale 1:750,000.

Jessey, D.R., Tarman, D.W., Waki, M., and Baltzer, S.M., 2001, A field investigation of the Clark Mountain fault complex, San Bernardino County, California, in Reynolds, R.E., ed., The changing face of the east Mojave Desert: California State University, Desert Studies Consortium, Fullerton, California, p. 46-49.

Jessey, D.R., 2013, Thrust overlook, in Parmentier, P., ed., Eastern Mojave Desert geology, mining, and earth resources: South Coast Geological Society Annual Field Trip Guidebook, no. 40, October 4-6, 2013, p. 97-100.

Kucks, R.P., Hill, P.L., and Ponce, D.A., 2006, Nevada magnetic and gravity maps and data-A website for the distribution of data: U.S. Geological Survey Data Series 234, accessed April 13, 2012, at http://pubs.usgs.gov/ds/2006/234.

Langenheim, V.E., Biehler, S., Negrini, R., Mickus, K., Miller, D.M., and Miller, R.J., 2009, Gravity and magnetic investigations of the Mojave National Preserve and adjacent areas, California and Nevada: U.S. Geological Survey Open-File Report 2009-1117, 25 p. 
Miller, D.M., Miller, R.J., Nielson, J.E., Wilshire, H.G., Howard, K.A., and Stone, Paul, 2007, Preliminary geologic map of the East Mojave National Scenic Area, California, in Theodore, T.G., ed., Geology and mineral resources of the East Mojave National Scenic Area, San Bernardino County, California: U.S. Geological Survey Bulletin 2160, scale 1:125,000 accessed February 2, 2009, at http://pubs.usgs.gov/bul/b2160/.

Morelli, C., ed., 1974, The International Gravity Standardization Net 1971: International Association of Geodesy Special Publication 4, 194 p.

Nelson, D.R., Chivas, A.R., Chappell, B.W., McCulloch, M.T., 1988, Geochemical and isotopic systematics in carbonatites and implications for the evolution of ocean-island sources: Geochimica et Cosmochimica Acta, v. 52, p. 1-17.

Nesbitt, B.E., Kelly, W.C., 1977, Magmatic and hydrothermal inclusions in carbonatite of the Magnet Cove complex, Arkansas: Contributions to Mineralogy and Petrology, v. 63, p. 271-294.

Olson, J.C., Shawe, D.R., Pray, L.C., and Sharp, W.N., 1954, Rare-earth mineral deposits of the Mountain Pass District, San Bernardino County, California-Rare earth deposits, San Bernardino County, California: U.S. Geological Survey Professional Paper 261, 75 p., 13 pls.

Plouff, D., 1966, Digital terrain corrections based on geographic coordinates [abs.]: Geophysics, v. 31, no. 6, p. 1,208.

Plouff, D., 1977, Preliminary documentation for a FORTRAN program to compute gravity terrain corrections based on topography digitized on a geographic grid: U.S. Geological Survey Open-File Report 77-535, $45 \mathrm{p}$.

Ponce, D.A., 1997, Gravity data of Nevada: U.S. Geological Survey Digital Data Series DDS-42, 27 p., CDROM.

Roberts, C.W., and Jachens, R.C., 1986, High-precision gravity stations for monitoring vertical crustal motion in southern California: U.S. Geological Survey Open-File Report 86-44, 76 p.

Roberts, C.W., and Jachens, R.C., 1999, Preliminary aeromagnetic anomaly map of California: U.S. Geological Survey Open-File Report 99-440, 14 p.

Shive, P.N., Nyblade, A.A. and Wittke, J.H. (1990) Magnetic properties of some carbonatites from Tanzania, East Africa. Geophysical Journal International, 103, 103-109.

Stewart, J.H., and Carlson, J.E., 1978, Geologic map of Nevada: Nevada Bureau of Mines and Geology Map, scale 1:500,000.

Swanson, S.C., McPherron, R.L., Searls, C.A., and Luyendyk, B.P, 1980, A geological and geophysical investigation of the extension of the Clark Mountain fault into Ivanpah Valley, Ivanpah quadrangle, California, in Fife, D.L., and Brown, A.R., eds., Geology and mineral wealth in the California Desert: South Coast Geological Society, Dibblee Volume, no. 8, p. 495-504

Swick, C.A., 1942, Pendulum gravity measurements and isostatic reductions: U.S. Coast and Geodetic Survey Special Publication 232, 82 p.

Theodore, T.G., ed., 2007, Geology and mineral resources of the East Mojave National Scenic Area, San Bernardino County, California: U.S. Geological Survey Bulletin 2160, accessed February 2, 2009, at http://pubs.usgs.gov/bul/b2160/.

Tosdal, R.M., 2007, General geologic setting, in Theodore, T.G., ed., Geology and mineral resources of the East Mojave National Scenic Area, San Bernardino County, California: U.S. Geological Survey Bulletin 2160, p. 10-11, accessed February 2, 2009, at http://pubs.usgs.gov/bul/b2160/.

Wooden, J.L., and Miller, D.M., 1990, Chronologic and isotopic framework for Early Proterozoic crustal evolution in the eastern Mojave Desert region, southeastern California: Journal of Geophysical Research, v. 95 , no. B12, p. 20, 133-20, 146.

Woolley A.R., and Kempe, D.R.C., 1989, Carbonatites: nomenclature, average chemical compositions and element distribution, in Bell, K., ed., Carbonatites: Genesis and Evolution: Unwin Hyman, London, p. 1-14. 


\section{Appendix A. Gravity Base Stations}

GRAVITY BASE STATION

\begin{tabular}{|c|c|}
\hline $\begin{array}{l}\text { NAME } \\
\text { PRIMM }\end{array}$ & $\begin{array}{l}\text { CITY/STATE } \\
\text { Primm, Nevada }\end{array}$ \\
\hline $\begin{array}{l}\text { LATITUDE/LONGITUDE/ELEVATION (NAD27/29) } \\
35^{\circ} 36.37^{\prime} \\
115^{\circ} 23.24^{\prime}\end{array}$ & $\begin{array}{l}\text { ACIC Reference No. } \\
\text { N.A. }\end{array}$ \\
\hline $\begin{array}{l}\text { OBSERVED GRAVITY (IGSN71) } \\
979,516.18 \text { milligals }\end{array}$ & $\begin{array}{l}\mathrm{n}=3, \text { from PB1021, California } \\
\text { (Roberts and Jachens, 1986). }\end{array}$ \\
\hline
\end{tabular}

DESCRIPTION

The station is located near the California-Nevada border in Primm, Nevada, at the Primm Valley Resort and Casino on the southeast side of Interstate Hwy 15. The station is located on the southeast corner of a shopping mall attached to the Resort near a loading-dock driveway. Place the meter on a concrete slab in the corner of the building and read the meter toward the building or approximately north.

\section{SKETCH/PHOTO}

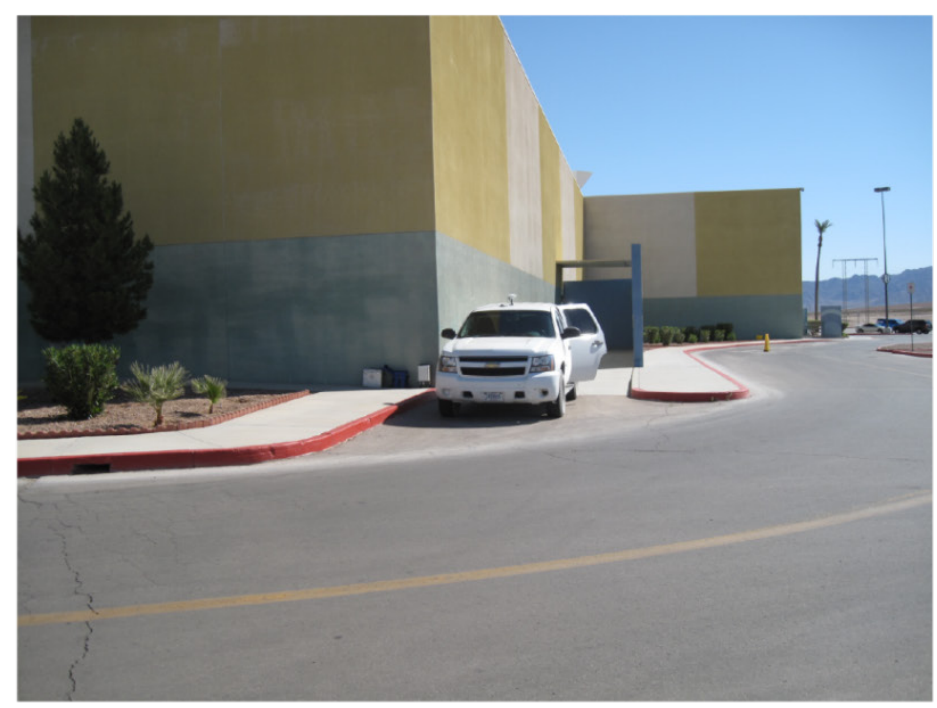

\section{REFERENCES}

Roberts, C.W., and Jachens, R.C., 1986, High-prescision gravity stations for monitoring vertical crustal motion in southern California: U.S. Geological Survey Open-File Report 86-44, 76 p. 
GRAVITY BASE STATION

\begin{tabular}{|l|l|}
\hline $\begin{array}{l}\text { NAME } \\
\text { PVR-A }\end{array}$ & $\begin{array}{c}\text { CITY/STATE } \\
\text { Primm, Nevada }\end{array}$ \\
\hline $\begin{aligned} \text { LATITUDE/LONGITUDE/ELEVATION (NAD27/29) } \\
35^{\circ} 36.37^{\circ} \quad 115^{\circ} 23.24^{\prime} \quad 2611.6 \mathrm{ft}(\mathrm{GPS})\end{aligned}$ & $\begin{array}{c}\text { ACIC Reference No. (Jablonski, 1974) } \\
\text { N.A. }\end{array}$ \\
\hline $\begin{array}{l}\text { OBSERVED GRAVITY (IGSN71) } \\
\text { 979,518.98 milligals }\end{array}$ & (n=5, from gravity station PRIMM, Nevada). \\
\hline DESCRIPTION &
\end{tabular}

The station is located near the California-Nevada border in Primm, Nevada, at the Primm Valley Resort and Casino on the southeast side of Interstate Hwy 15. Station is on the northeast side of Building A, near a fire hydrant in the northeast corner of the parking lot. Place the meter in the corner of a cement curb near the fire hydrant and read facing the fire hydrant or approimately northward.

SKETCH/PHOTO

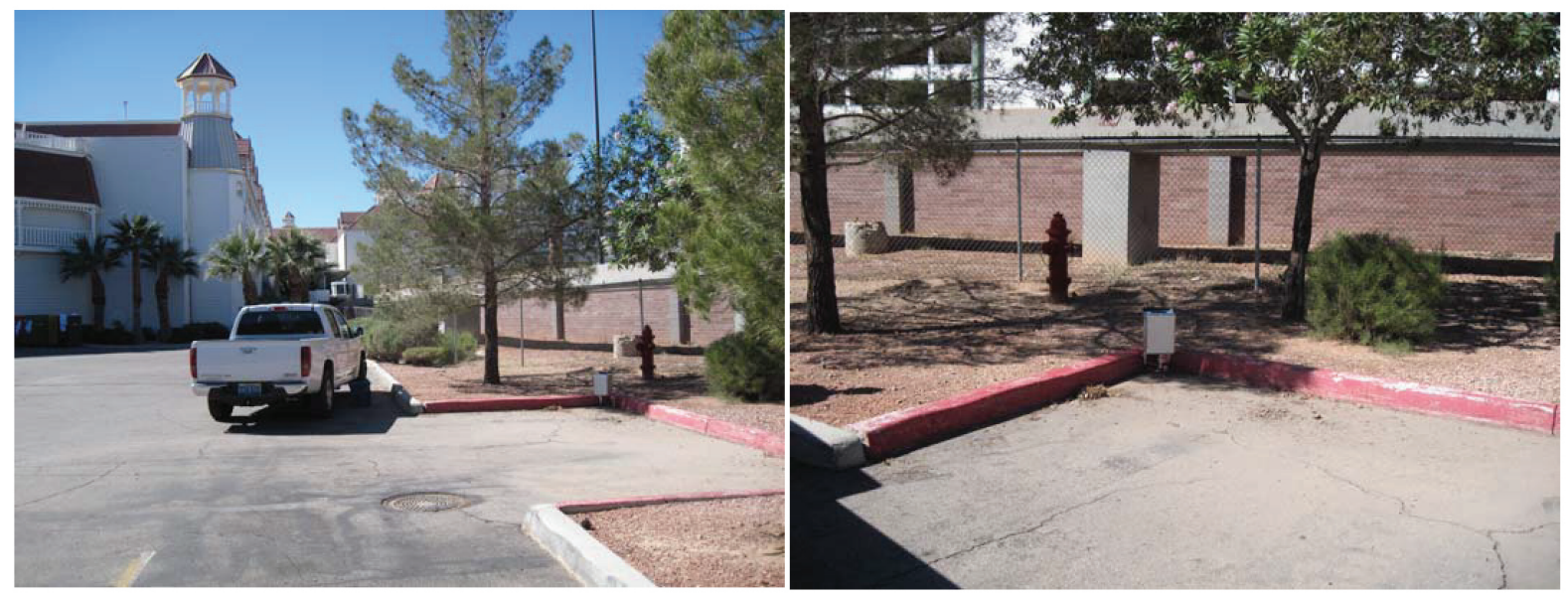

REFERENCES

Kevin M. Denton and David A. Ponce, U.S. Geological Survey, 2012 
GRAVITY BASE STATION

\begin{tabular}{|l|l|}
\hline $\begin{array}{l}\text { NAME } \\
\text { MTN PASS }\end{array}$ & $\begin{array}{c}\text { CITY/LOCATION/STATE } \\
\text { Mountain Pass, California }\end{array}$ \\
\hline $\begin{array}{l}\text { LATITUDE/LONGITUDE/ELEVATION (NAD27/29) } \\
35^{\circ} 28.02^{\prime} \quad 115^{\circ} 31.65^{\prime} 4633.2 \mathrm{ft}(\mathrm{GPS})\end{array}$ & $\begin{array}{c}\text { ACIC Reference No. } \\
\text { N.A. }\end{array}$ \\
\hline $\begin{array}{l}\text { OBSERVED GRAVITY (IGSN71) } \\
979,377.46 \text { milligals }\end{array}$ & $(\mathrm{n}=3$, from PRIMM, Nevada). \\
\hline
\end{tabular}

DESCRIPTION

The station is located along Interstate Hwy 15 at the Bailey Road exit at Mountain Pass, California. The station is on the south side of the freeway, about $100 \mathrm{ft}$ south of the east bound on ramp. Place the meter on the road adjacent to a curb and a "STOP sign. Read the meter facing north.

\section{SKETCH/PHOTO}
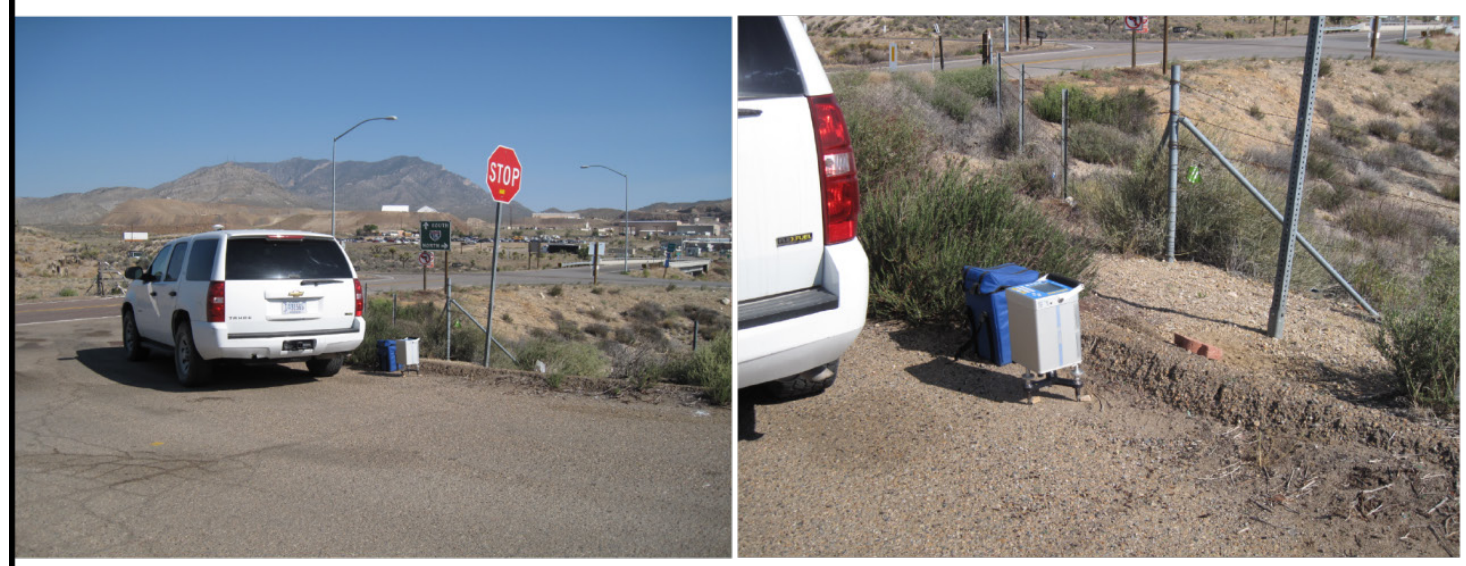

REFERENCES

Kevin M. Denton and David A. Ponce, U.S. Geological Survey, 2012 
GRAVITY BASE STATION

\begin{tabular}{|l|l|}
\hline $\begin{array}{l}\text { NAME } \\
\text { PB1021 }\end{array}$ & $\begin{array}{c}\text { CITY/STATE } \\
\text { Near Baker, California }\end{array}$ \\
\hline $\begin{array}{l}\text { LATITUDE/LONGITUDE/ELEVATION (NAD27/29) } \\
35^{\circ} 23.29^{\prime} \quad 116^{\circ} 07.27^{\prime} 981.8 \mathrm{ft}(\mathrm{GPS})\end{array}$ & $\begin{array}{c}\text { ACIC Reference No. } \\
\text { N.A. }\end{array}$ \\
\hline $\begin{array}{l}\text { OBSERVED GRAVITY (IGSN71) } \\
979,627.615 \text { milligals }\end{array}$ & \\
\hline DESCRIPTION & \\
\hline
\end{tabular}

The station is located about $9.3 \mathrm{mi}$ north of Baker, $0.25 \mathrm{mi}$ east of State Highway 127 under the middle of three powerlines, about $325 \mathrm{ft}$ east of east leg of tower "71 I1 2" on marble outcrop flush with ground on north side of small hill east of power pole (midway between center and southernmost cables). No gravity marker.

An alternate station, PB1021 A is $20 \mathrm{ft}$ northeast of PB1021 on a marble outcrop that is marked with a standard gravity marker with an observed gravity value of 979,627.623 milligals.

\section{SKETCH/PHOTO}
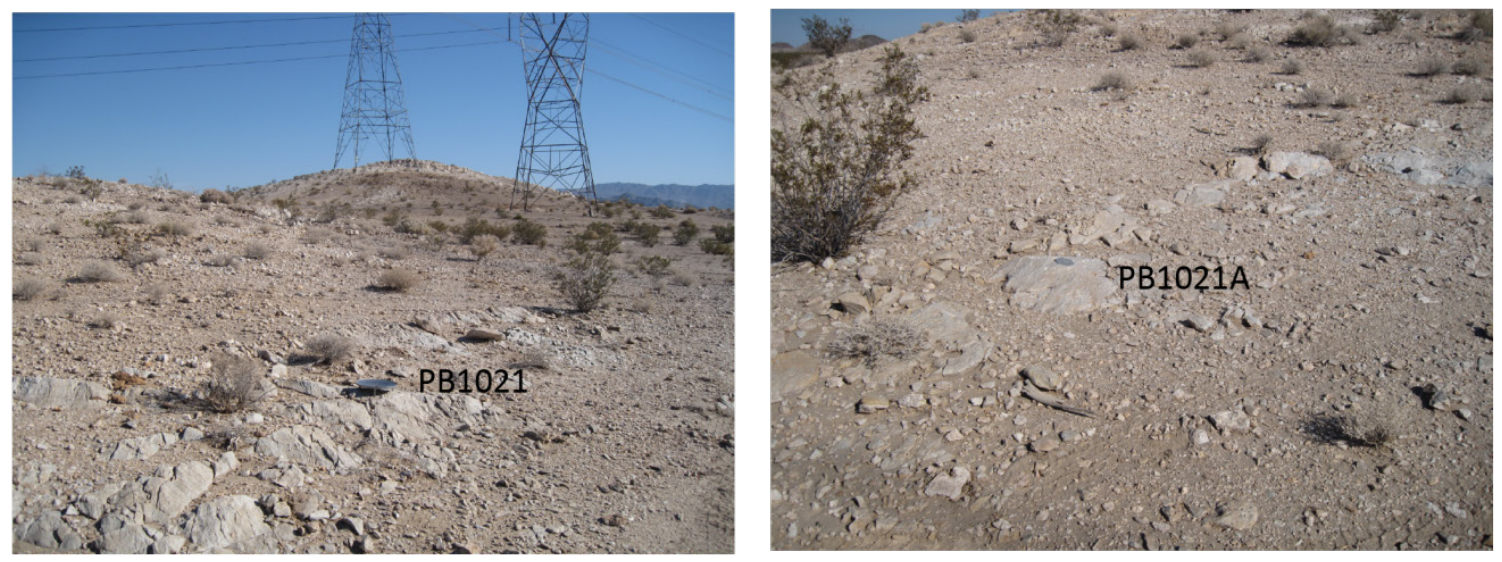

\section{REFERENCES}

Roberts, C.W., and Jachens, R.C., 1986, High-prescision gravity stations for monitoring vertical crustal motion in southern California: U.S. Geological Survey Open-File Report 86-44, 76 p. 
GRAVITY BASE STATION

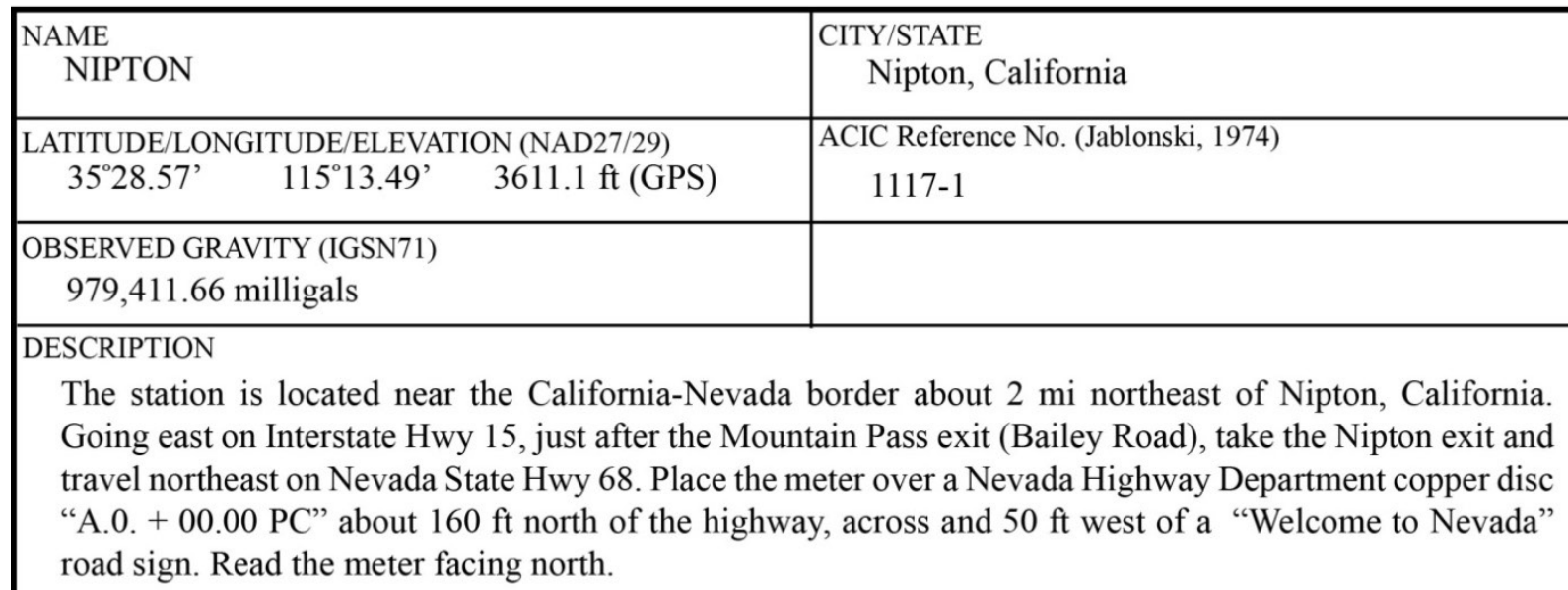

\section{SKETCH/PHOTO}

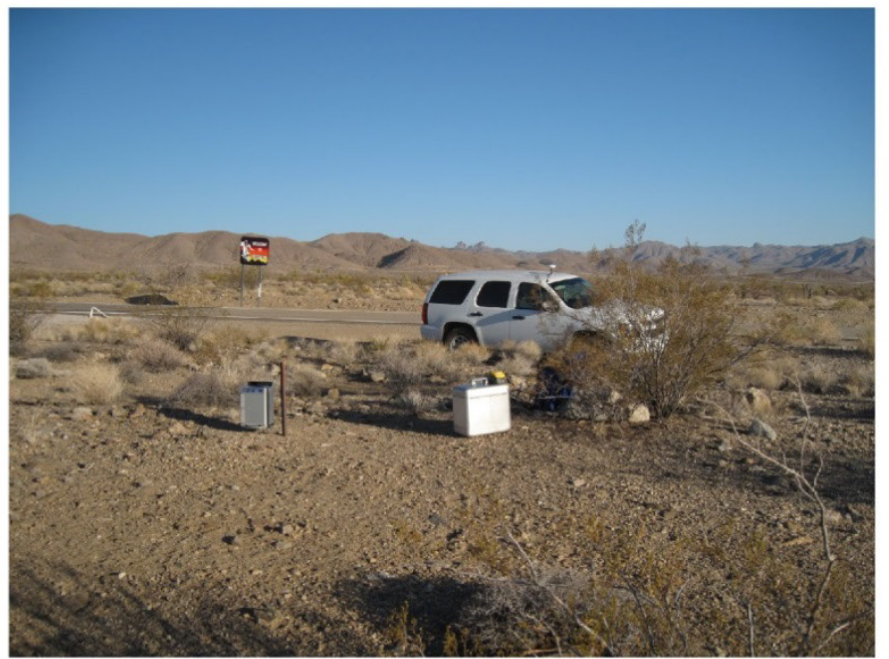

View looking southward

\section{REFERENCES}

Jablonski, H. M., 1974, World relative gravity reference network North America, Parts 1 and 2: U.S. Defense Mapping Agency Aerospace Center Reference Publication no. 25, originally published 1970, revised 1974, with supplement of IGSN 71 gravity datum values, $1261 \mathrm{p}$. 
This page left intentionally blank 
Publishing support provided by the U.S. Geological Survey Publishing Network, Tacoma Publishing Service Center

For more information concerning the research in this report, contact the Geology, Minerals, Energy, \& Geophysics Science Center U.S. Geological Survey, c/o University of Arizona ENRB Building, 520 N. Park Ave, Rm 355

Tucson, Arizona 85719-5035

http://geomaps.wr.usgs.gov/gmeg/ 
